\title{
Parody Idioms in the Visual Characteristics of KNIL Andjing NICA Reenactors
}

\author{
Andrian Dektisa \\ Graduate School, Indonesia Institute of the Arts Yogyakarta 55141, Indonesia \\ email: andyt868@gmail.com
}

\begin{abstract}
This research is to study the phenomena of wearing military costumes of the past as an alternative 'means' of visual communication. People in Indonesia like old military costumes and celebrate them as reenactors (a name for the wearers of old military uniforms) in various social activities that can be categorized into two types of stage, namely main and parallel stage. The main stage is related to learning military history, while parallel stage correlates to euphoria for military fashion. Both stages become an expression of mockery toward postcolonial mimicry and create a cultural postcoloniality that takes place in the contemporary life in Indonesia. This research applies Rose's visual method that emphasizes the aspect of site image itself by making interviews and getting observation data in the groups of KNIL Andjing NICA reenactors in Surabaya, Bojonegoro, Bandung, and Jakarta. It also applies Barthian semiotics unit analysis.

Keywords: parody idioms, reenactors, visual character.
\end{abstract}

\section{INTRODUCTION}

This research studies the visual characteristics of KNIL Andjing NICA reenactorsas they can be found in recent years in Bandung, Jakarta, Yogyakarta, Surabaya and Semarang. The appearance of the visual charateristics is an embodiment of euphoria in liking everything related to the military and war in the past. This phenomenon grows to be a new hobby, that is liking the soldier'scostumes, which has developed in Indonesia since 2011. The enactors, a name for subjects wearing military costumes (Webster, 2015), besides putting on soldier's costumes, also act out the popular and legendary war happening in Indonesia, such as Bandung Sea of Fire, Surabaya 10th November War, Serangan Umum Satu Maret in Jogja, Magelang Battleground Rises Again, and others. The reenactors are included in reenactment groups such as Historische Van Bandoeng (HVB), Roodebrook Soerabaia, or Babad Bandayuda Yogyakarta, which have appeared and become popular since 2010.

In doing their activities the reenactors put on replica/counterfeit uniforms (costumes) and properties (war tools/attributes) that are adapted to the war period/era in accordance with the play they act out. Generally, the groups are divided according to the parties involved in the war as it really happened in the past. Therefore, it is not unusual to find reenactors acting out as independence warriors, for example as the army of Badan Keamanan Rakjat, Tentara Keamanan Rakjat, Tentara Pelajar, LASWI, and others, or as enemy soldiers (Japan, England, Gurkha, KNIL). The activities in the reenactment give rise to the trend of liking the visual characteristics in the form of 
military costumes of the past.

\section{MATERIALS AND METHODS}

The object of analysis in this paper is the reenactors who are putting on KNIL Andjing NICA's uniforms of the independence war period of 1945-1949. The visual impression groups are interesting to be analyzed because:

1. As if Indonesianpeople at present celebrated the visual characteristics of KNIL Andjing NICA's soldiers, who were recorded as enemy soldiers in the history of Indonesian independence and as traitors well-known for their cruelty.

2. The researcher of this paper views the visual characteristics of KNIL Andjing NICA's soldiers as a phenomenon of visual arts because it becomes people's expression at present in imitating the things done in the era of Dutch East Indies. This apparently becomes a kind of 'celebration'and euphoria in visualizing the characteristics of KNIL soldiers by making up their appearance with various accesories and attributes.

3. The expression of visual characteristics of KNIL Andjing NICA reenactorsbecomes a kind of mimetic artifact of colonial KNIL Andjing NICA soldiers, and can be related to the concept of mimicry in postcolonial theory, namely as an attempt to imitate or borrow various elements and colonial signs by the colonized people. The imitation practice blends the elements and produces a new identity and formation that bring out certain characteristics of each element.This is called hybrid identity, which is one of the concepts in Homi K. Bhabha's postcolonial study (1994:120) that will be a starting point for the analysis in this research.

There are many activities the reenactors do as a part of their visual expression, but based on the characteristics of their activities they can be categorized into two types, namely activity related to the reenactment ofwar history and activity that is not at all related to history. The Main Stage is a special name in this research for the reenactors' activity that is concerned with celebrating history, for examplethe celebration of independence war moments that happened in Indonesia in the past; while Parallel Stage is for the reenactors' activity that is non-historical, for instance taking a walk on Malioboro street or a tour to Yogyakarta palace, bicycling leisurely on car-freeday Sundays, and many others.This research studies the phenomenon of reenactors' activity in two different stages, namely the Main Stage and Parallel Stage.

The following are examples of visual apperance of soldier characters in the Main Stage

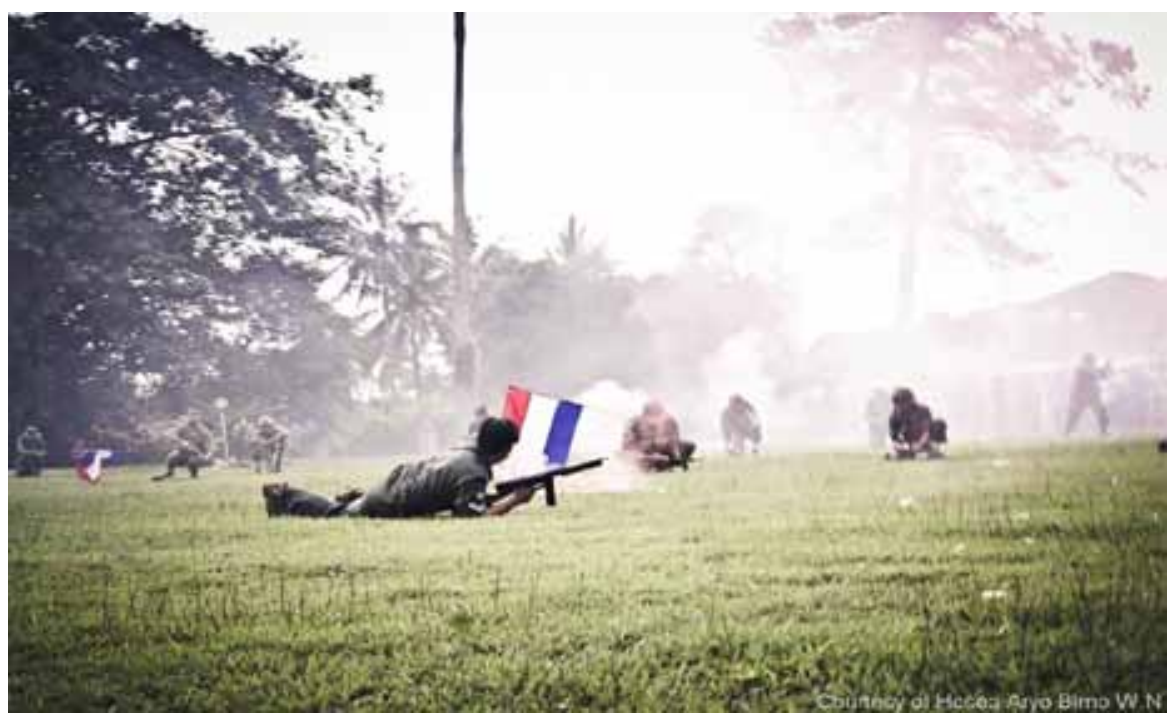




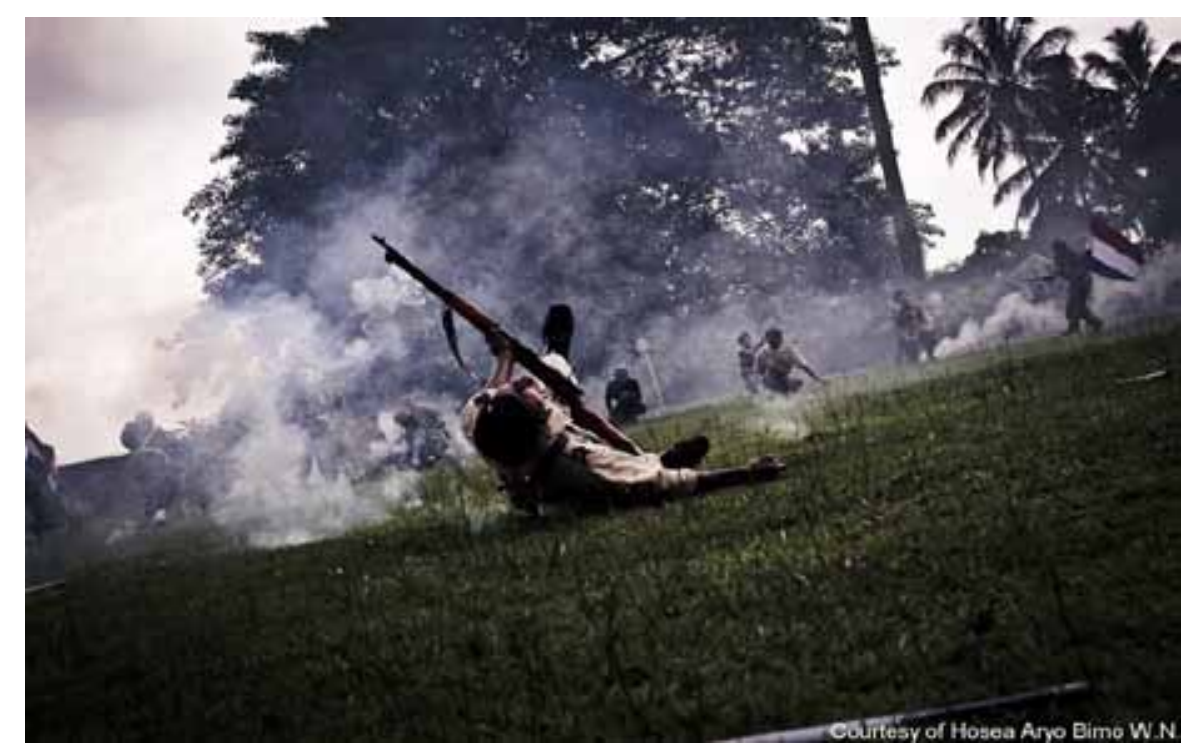

Figure 1. Reenactors' activityin theatrical action celebrating Magelang Battleground Rises Again, 2014 in Magelang. (Collection: Andrian Dektisa's).
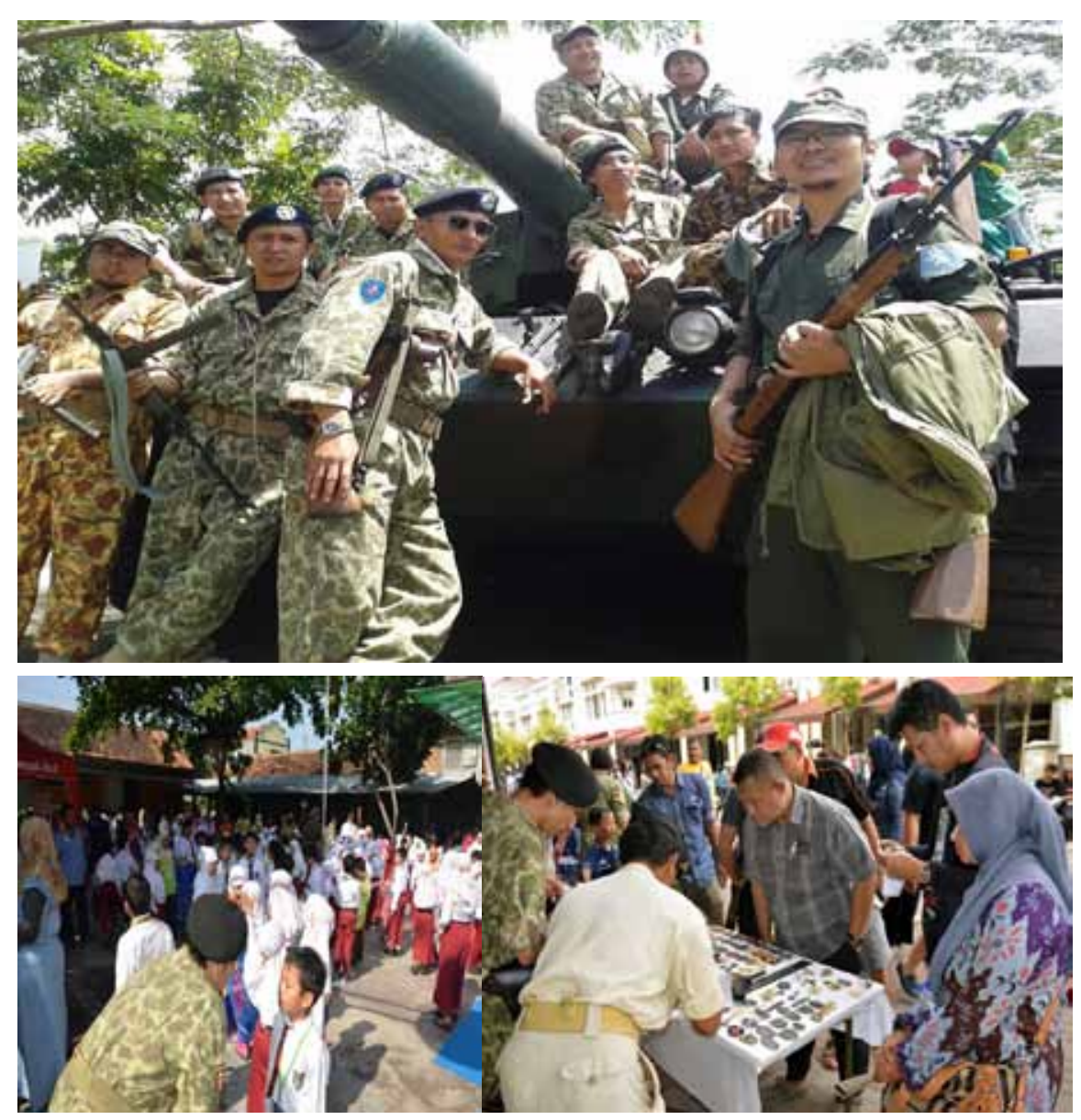

Figure 2. Reenactors' activityin historical dispay of the military in Bandung, 2014 (Collection: Hosea Bimo's). 

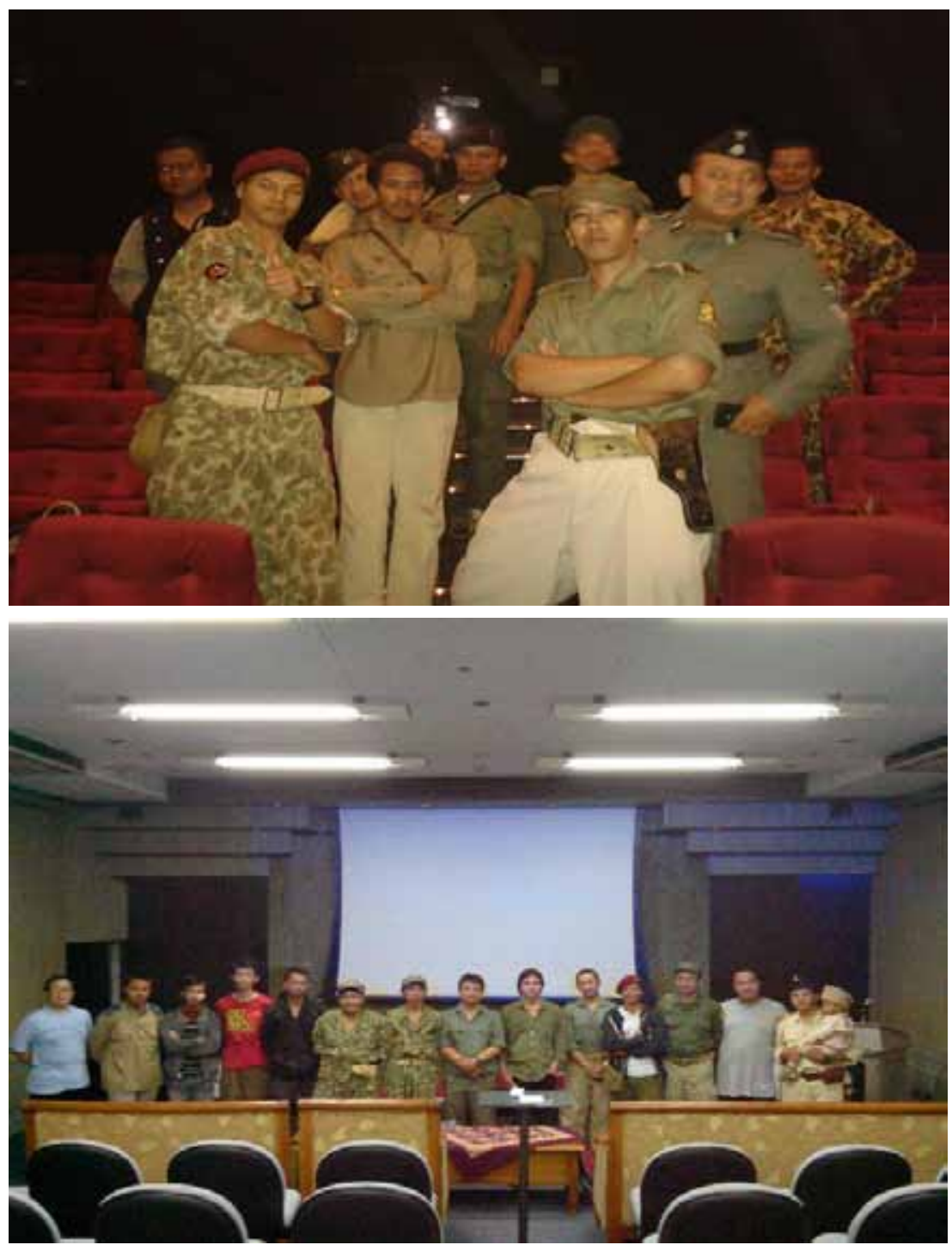

Figure 3. Activity of watching the film Fury (above), and discussion on the film Oeroeg (below), reenactor members of HvB in Bandung. Top picture: One of the reenactorswas putting on KNIL's army costumeswith bagde Andjing NICA's blue badge.( Collection : HvB, 2015). 
While Parallel Stage activities can be seen in the following pictures:

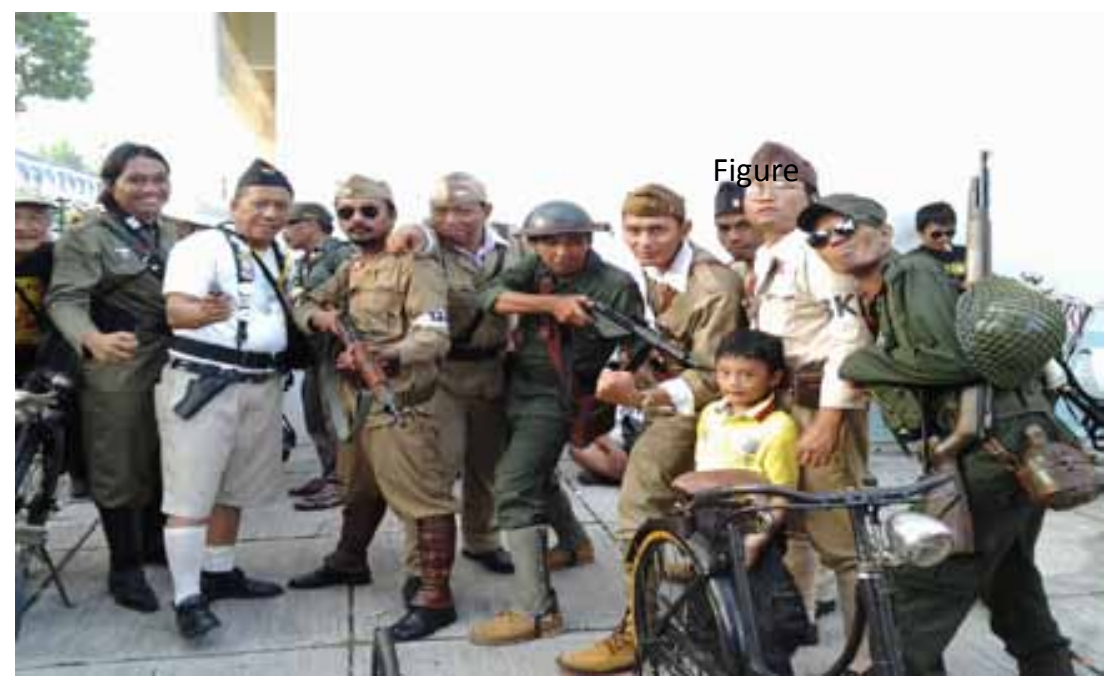

4. Various reenactors' impressionof bicyclers' (called ontelis in Indonesian) military costumes of 1940sin old bicyle riding in Surabaya 2012. (Collection: Rubbin Nanda's, 2012).

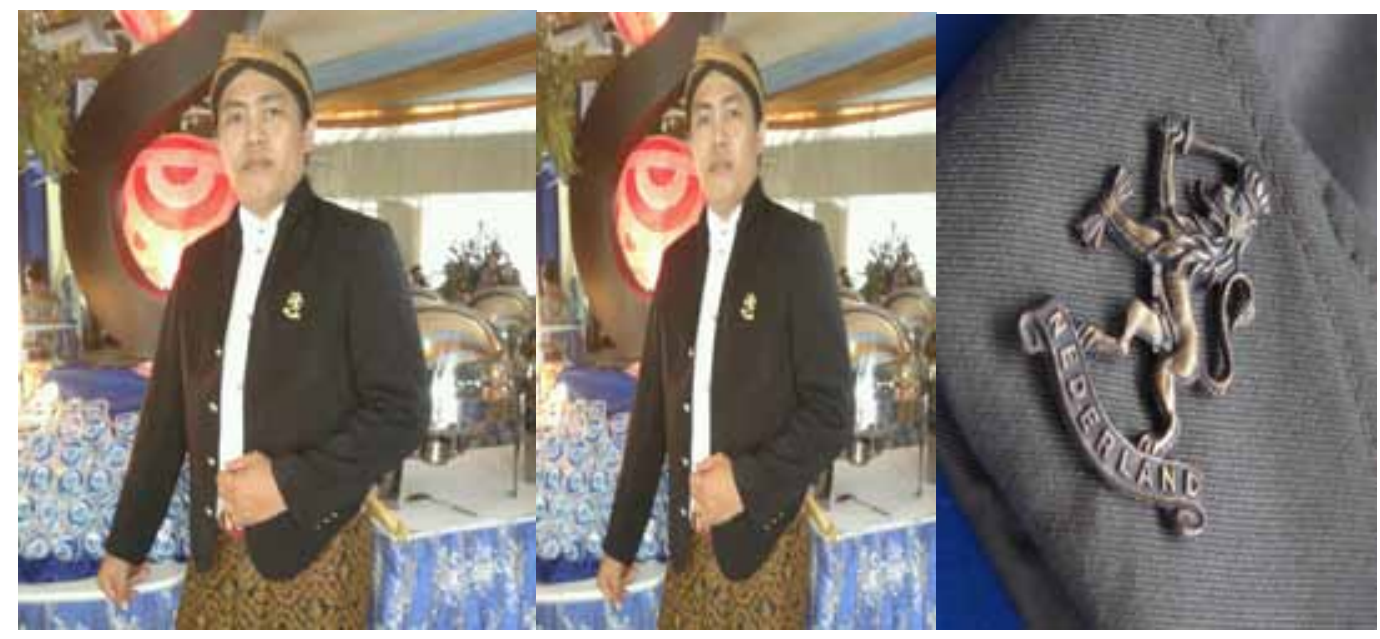

Figure 5. Maitendraai Koninlijk Insignia KNIL's pinattached on Javanese tight-fitting short jacket at a wedding ceremony. (Collection: Febri Asnan's , 2014).

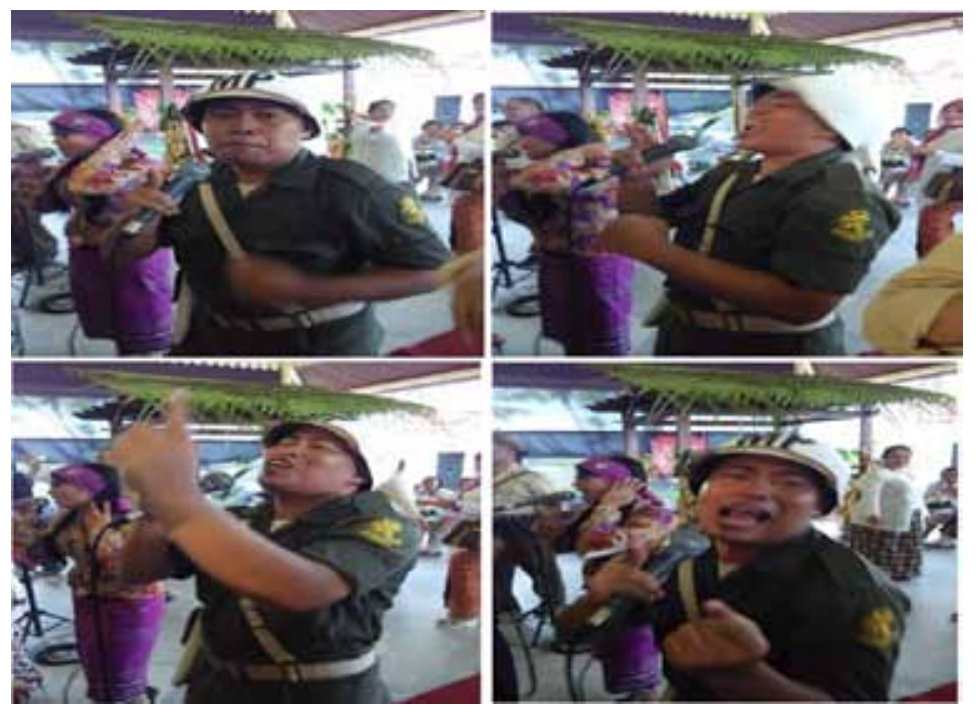

Figure 6. KNIL's costumesworn by an amateur singer at a wedding party in Magelang (Collection: Febri's collections, 2014). 

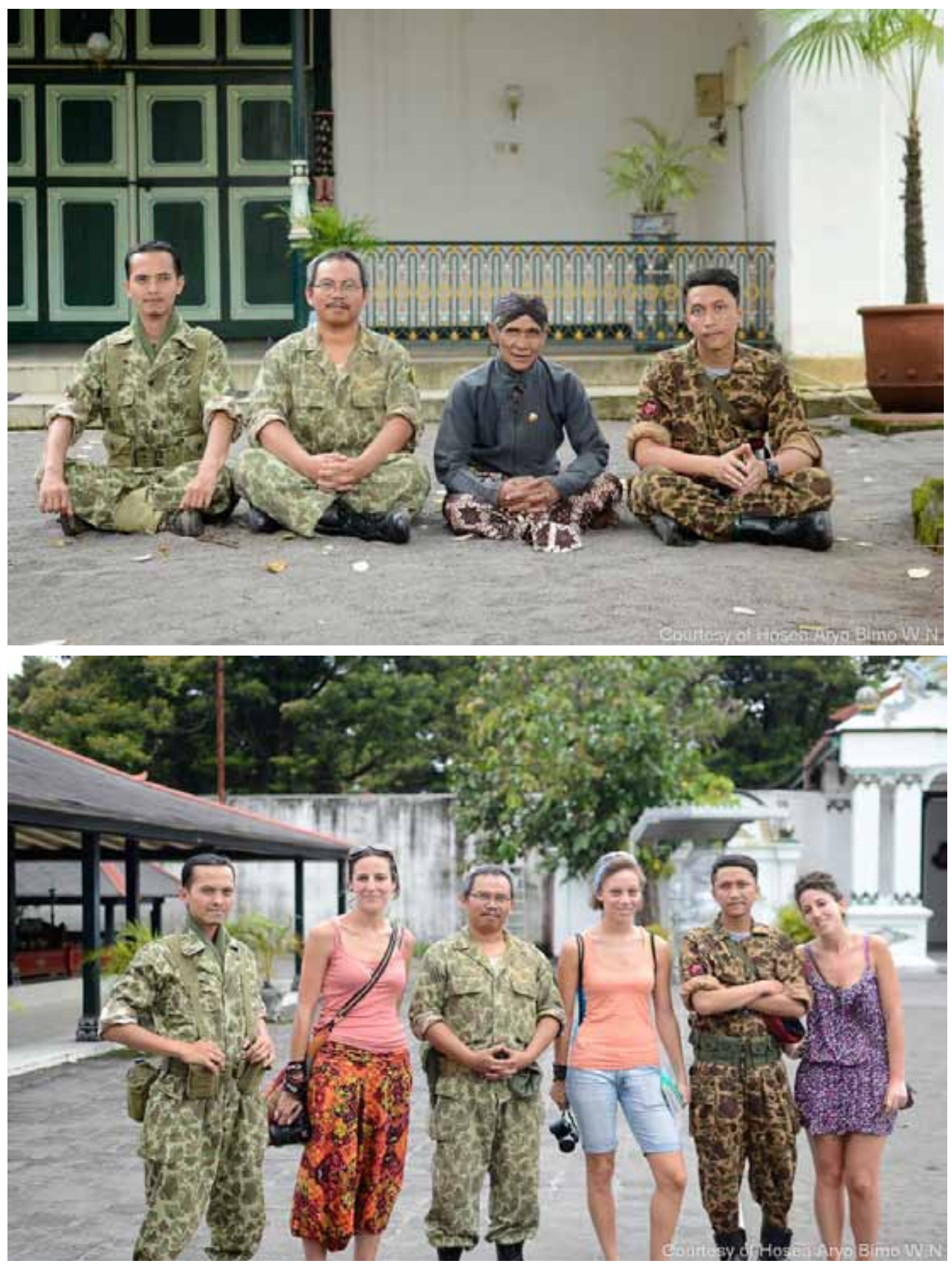

Figure 7. Reenactors' impression of KNIL Andjing NICA soldiersvisitingYogyakarta palace and taking picture with royal servants and tourists, 2015.

\section{Statement of the Problem}

The problem that will be studied in this article is why the visual characteristics of KNIL Andjing NICA soldiersat present are interpreted in the form of parody?

\section{Research Method}

This research applies interview and observation on the reenactors doing the reenactment and social activities in KNIL Andjing NICA soldier replica costumes 
for data collection. The data are documented in pictures collected from June2013 to Agustus 2015. The interview was carried out to 10 reenactors who acted out visual characters of KNIL Andjing NICA soldiersliving in Jakarta, Bandung, Yogyakarta and Surabaya. The observationwas done by watching closely and documenting the activities of the reenactorsin KNIL Andjing NICA soldier replica costumes in Bandung, Yogyakarta, Magelang and Surabaya.

The methodof data analysis applies Gillian Rose's visual methodology (2007) emphasizing on the site image itself considering the aspects of the site of production and the site of audiencing as an analysis support to obtain a more profound signification on the material objects. The main theory applied in this analysis is postcolonial one that is assumed to operate through visual expression in the form of costumes and military replica gears of KNIL Andjing NICA soldiers.

\section{DISCUSSION}

a. Visual mimicry in the form of characters' costumes of KNIL Andjing NICA soldiers Costumes and accesories worn by KNIL Andjing NICA reenactors in the Main Stage and Parallel Stage activities are the same, namely characters' replica costumes of KNIL Andjing NICA soldiers. The visual characteristics in the form of KNIL Andjing NICA soldier reenactorsseem to be an embodiment of colonial Dutch contextualization. Costume replica is a replica of military uniformsthat confirms hegemony and colonial power exercise, by which it can be interpreted as a form of mimicry/imitation of the application of colonial Dutch hierarchy and military uniforms system. It also applies to the equipments of colonial products used as complementary accesories for the uniforms, for example gun replica, old bycicles, pipes, and many more. All the objects were colonial Dutch's means to make a social-economic stratification and were an embodiment of social behavior occuring in the Dutch East Indies era.

The following are examples of visual imitation of the KNIL Andjing NICAsoldier characters:

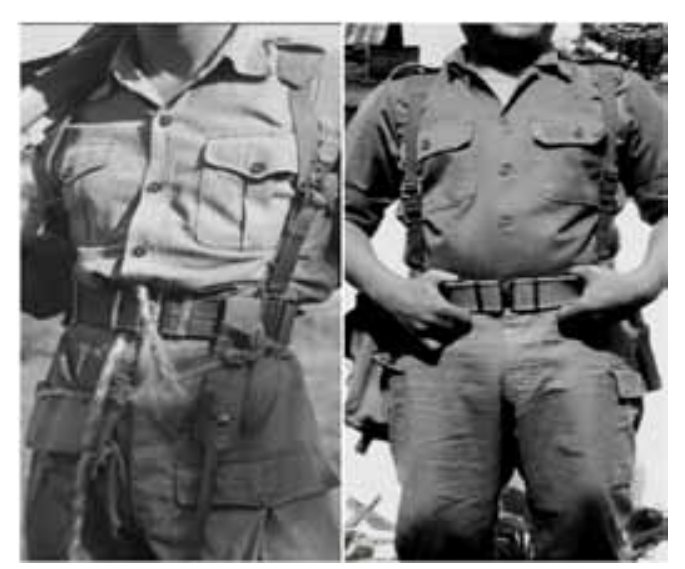

Figure 8. The picture on the left is a figure of KNIL soldier character of 1949 used as a reference. The picture on the right is a reenactor imitating the picture on the left. (Collection: Rae Wahyudiono's, 2014). 


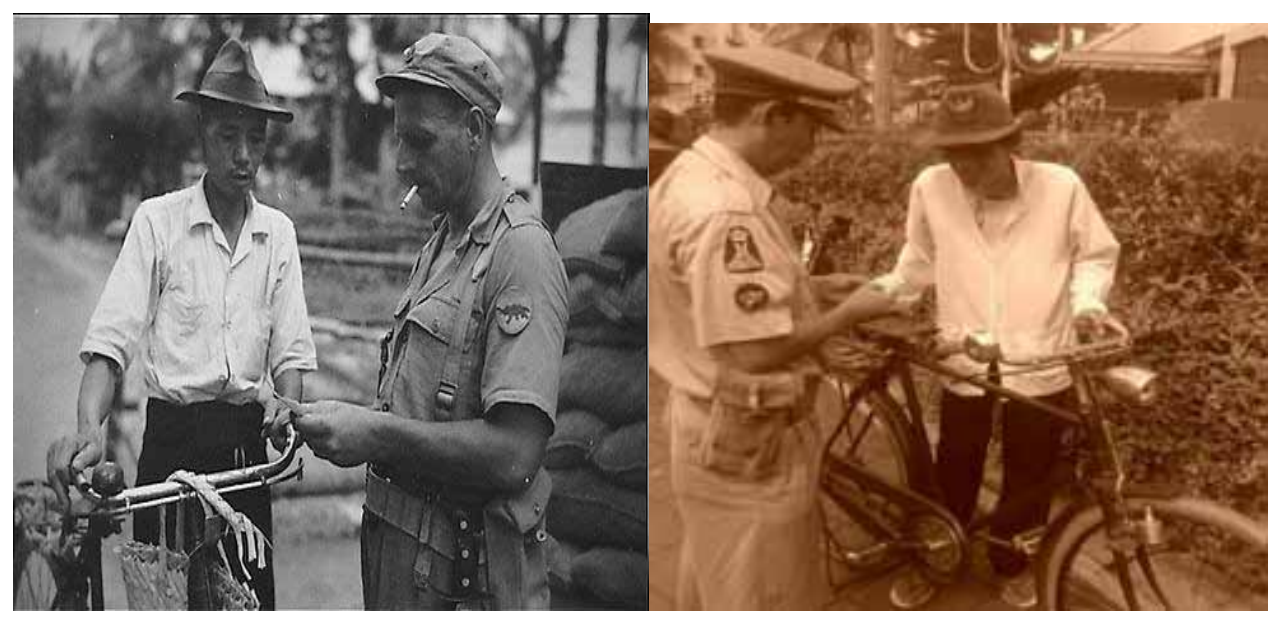

Figure 9. The picture on the right is a costume and setting imitation of past scene from the picture on the left. (Collection: Agung Setiawan's, 2014).

The word 'mimicry'according to Glossarium Indonesian Dictionary(2014) means a form of behavior or appearance that first grows in some animals, especially insects, in which the species imitates other species in terms of behavior or appearance as a way to avoid threat in a confrontation with predators. The example is a flower fly, many of which look like bees. The concept of mimicryfirst introduced by Franz Fanon in Black Skin, White Mask (1952) saying that the colonized people were forced to take off their traditional view of their selves and national identity and then started to learn to adapt their identity with their masters'.

The concept of mimicryis used to describe the process of imitating or borrowing various cultural elements. Mimicry phenomenon does not reflect a dependence of the colonized on the colonizers, instead the imitators enjoy and play with the ambivalence in the imitation process. Mimicryis caused by an ambivalent relationship between the colonizers and the colonized. This ambivalent attitude is triggered by loving and at the same time hating something. According to Bhabha, this ambivalenceshould not only be read as a sign of the colonial subject's traumabut also as a characteristic of the colonial autority operation and as an expression of resistant dynamics at the same time. Furthermore, Bhabha also said that the colonial presence was always ambivalent, divided between presenting itself as original and authoritative and having an articulation that revealed repetition and difference. In other words, colonial identity is unstable, doubtful, and always divided (Loomba, 2003: 229-230). Homi Bhabha understood mimicrybehavior as an attempt of imitation by the Black toward the White that involved resistence.

Concerning mimicry as a form of resistence, Murwani (2007:p.15) said that mimicrywas a behavior carried out as a result of inferior feeling covered up by imitating the behavior of those deemed to be superior. They denied and fought against their own lackness reflected by those who were superior by showing similar capability. Richard King (1999) said that the relationship between the colonized and the colonizer was competitive in nature, meaning that the mimickingperson at the same time wanted to show their competitive power. By imitating and also showing his/her capability no 
less inferior than those s/he imitated, his/her competitive power was no more a mere means of survival but a weapon to strike back.This happens because mimicryalways indicates an inappropriate and misplaced meaning.It is an imitation and the same time a subversion. Thus, mimicrycan be viewed as a strategy to face the colonizer's domination. Like a camouflage, it is ambivalent, perpetuating but also negating its domination. It can be seen that mimicryis the basic of hybrid identity.

Mimicry in relation to its material object can be found in imitating behavior carried out by the reenactors in character visualization of the figures other than their own characters.Mimicryin reenactorsis not an attempt to avoid an enemy's threat but even a part of euphoria celebrating to be a visual representation of the enemy, due to a demand for visual imitation for the stage in the signification. Mimicryreenactor is said to be total if $\mathrm{s} /$ he looks similar as close as possible to the figure $\mathrm{s} /$ he imitates..

Reenactor is a person who lives at present and carries out visual character impression refering to historical document; thus, it can be assumed that s/he imitates an enemy's visual character figure of different era and not for the reason of avoiding a danger likethe concept of mimicry in animal, namelyit is carried out to look alike with its enemy. Between mimicryreference figure and mimicryimitation there is a difference in time, and the imitator is not threatened by its patterns. Therefore, mimicryin reenactor is the most supervicial attempt of copyingbecause it only imitates the appearance and its imitation is only on the surface.

KNIL soldiers of local ethnicity in independece revolutionary era imitated the visual character of the Dutch soldiers because both became a member of platoon carrying out a duty for the colonial interest. Therefore, it can be said that KNIL soldiers of local ethnicity mimicked for the causes related to survival needs. Thus, it can be understood that mimicrywas an attempt to acquire qualified life standards due to the lack of income and skill. While mimicryin the reenactorsseems to be a banal mimicrybecause it is not related to a world view or survival, but it is a visual mimicryof KNIL soldier charactersas an activity to get fun.

In the material objects, there are two levels of mimicrythat I call 'double mimicry,' namely reenactors' mimicryover historical visualized figures of KNIL Andjing NICA's soldiers of local ethnicity who mimicked the Dutch characters and styles. In other words, historical documentation about the visual characters of KNIL soldiers of local ethnicity in the independence war is a mimicryof 'their white masters' and at present the figures become patternss to be mimicked by the reenactors. This is a mimicry over a historical mimicry.

The first mimicrycarried out by KNIL soldiers in the independence war era can be a good example of local expression categorized by Pramayosa (2013:8). It is an intrinsic individual condition as a part of colonized society. In relation to KNIL soldiers, it was a condition to be lived by an individual incarrying out the colonial army duty.

Local expression as a mimicryconstruct does not work fully, but a situation of dividedness also appears (categorized to be a form of ambivalence) from the postcolonial subjects, namely between admiring and imitating and loving and the 
same time hating the colonizers as explained by Ashcroft (1995:139). This situasional dividedness of mimicryis called 'mockery'. Mockerycan be understood simply as a 'blurred imitation' and 'mocking imitation' that the postcolonial subjects try to do to the colonizers' culture (Ashcroft, 1995:139).

\section{b. Mimicry dan Mockery}

Hybrid identity of mimicrybehavior can never be fully controlled by colonial authority because there is an ambivalence incolonial discourse. Ambivalence is derived from psychoanalysis field that is used to describe the continuous fluctuation between wanting one thing and its opposite at the same time. In postcolonial discourse, ambivalence develops into a concept that explains the diversity of choices offered to the colonial subjects for identity formation. Ambivalence refers to a nature that is unstable, oppositional, and unidentical with colonial discourse.

This very ambivalencemakes mimicrydone by the colonized people never reach its fullness becauseof the ambivalent nature of the colonial discourse. Therefore, the colonialconstruct about the colonizers and about the colonized subjects can signify many things, even oppose each other. The imitation done by the colonized people over the lifestyles offered by the colonialdiscoursedoes not necessarily mean submissiveness of the colonized toward the colonizers.

On a certain level, mimicrybehavior can also be a mockery toward the colonizers becauseit does not fully imitate the models offered by the colonizers. Mimicryas an ambivalentdiscoursebuilds a similarity on one side andkeeps a difference on the other side. The culture of the colonizers not only can be imitated but also can be played around. Mimicrythen can be understood as a process that is imposed by the colonizers but is accepted by the colonized pretendingly (even with lying) to produce a situation that Bhabha called "almost the same, but not quite."

In the material objectsof this research, the mockery condition appears when there is a significant contrast betweenhistoricalmimicryof KNIL soldiersand the reenactors'euphoria over KNIL soldiers, inthe form of 'surfacial mimicry' becausethe imitation is only on the uniforms of KNIL soldiers. The mimicryonly imitates the visual aspects on the costume motifs popularly known as KNIL soldiers' identity with a motif of frog's skin. This 'frog skin mimicry'becomes an expression for what I think to be an expression in parallel stage. This frog skin mimicryis superficial in nature and is only carried out as an activity in contrast with its historical situation, and becomes a blurred mimicry or a mockery mimicry over the characters of KNIL Andjing NICA's soldiers.

Therefore, double mimicry category that appears in parallel stage is a form of mockery expression. The mockery condition also appears when mimicrycarried out does not take place perfectly because situasional differences that appear betweenthe patternssand their mimicry, such as time frame (past and present), social and cultural condition (point of view on the military uniforms as fashion, point of view on binary oppositions, for instance about antagonist-protagonistinthe relation with historical perspectives on Indonesian independence). 
In Bhabha's postcolonial perspectives, the concept of mimicry is used to describe the process of imitation or borrowing of various cultural elements. Mimicryphenomenon does not show the dependence of the colonized on the colonizers, but the imitators enjoy and play around with ambivalenceoccuring in the imitation process. Related to the materialobjects, this practice also appears when mimicryproduced is based on visual photo reference whose objectivity is doubted. It means a picture is a visual construct to communicate something. This communication purpose sometimes makes the picture imbued with interest, for example a picture visualizing a war very likely and inevitably produces constructs that benefit one of opposing parties.These constructs are understood in the journalistic photography as framing.

A picture published in a mass media has a framing content for the interest of the mass media; thus, it tends to be a visual fact with less objectivity. Mimicryproduced from a content that is not framing-free tends to create a contrast while the significance of the reenactors' mimicry is to achieve authenticity as optimal as possible. If there are visual data that oppose each other or are not congruent one with another, then the resultant mimicryis a confusing one becauseit is not standard, constantand flexible. Anyhow, I assume this to be also a form of mockery expression..

Situasional mockery also appears because mimicrypatterns does not come from the visualization of figure character from historical data, instead it comes from the previous reenactors' figurein which one of them has been visually and digitally modified with a computer. This happens due to the tendency of diaspora inthe reenactor figureand also due to a trend in the society. In other words, people imitate visual character of soldiers not in reference to a picture or authentic visual data in accordance with history but to visual objectsof KNIL soldier reenactorsas a result of their creativity or a product of digital picture editing. It is difficult to identity whether a picture is original or has been edited digitally by only looking at it. An activity that seems to 'play around' with colonial culture brought about by reenactorsbecomes an expression that blurs the mimicryitself, and the appearing mimicryis not a form of complete mimicry, yet it appears as a mocking one. This assumption will be used as one of the arguments that mimicryin reenactorsis a way to create a contrast situation, mockery, and fun-making of serious colonial faces.

Mockery expression also appears indaily life activities of reenactorswhen they mix their daily social activity with their reenactment one, especiallythe one related to fun expression in group activity. The mimicryconstruct then produces interconnection whose characteristic emotion is euphoria and shared happiness. The resulting fun becomes a visual construct that can be categorized as funny, and it is in complete contrast with its original mimicry patterns. This can be assumed as a form of parody expression.

The following are the visual examples: 

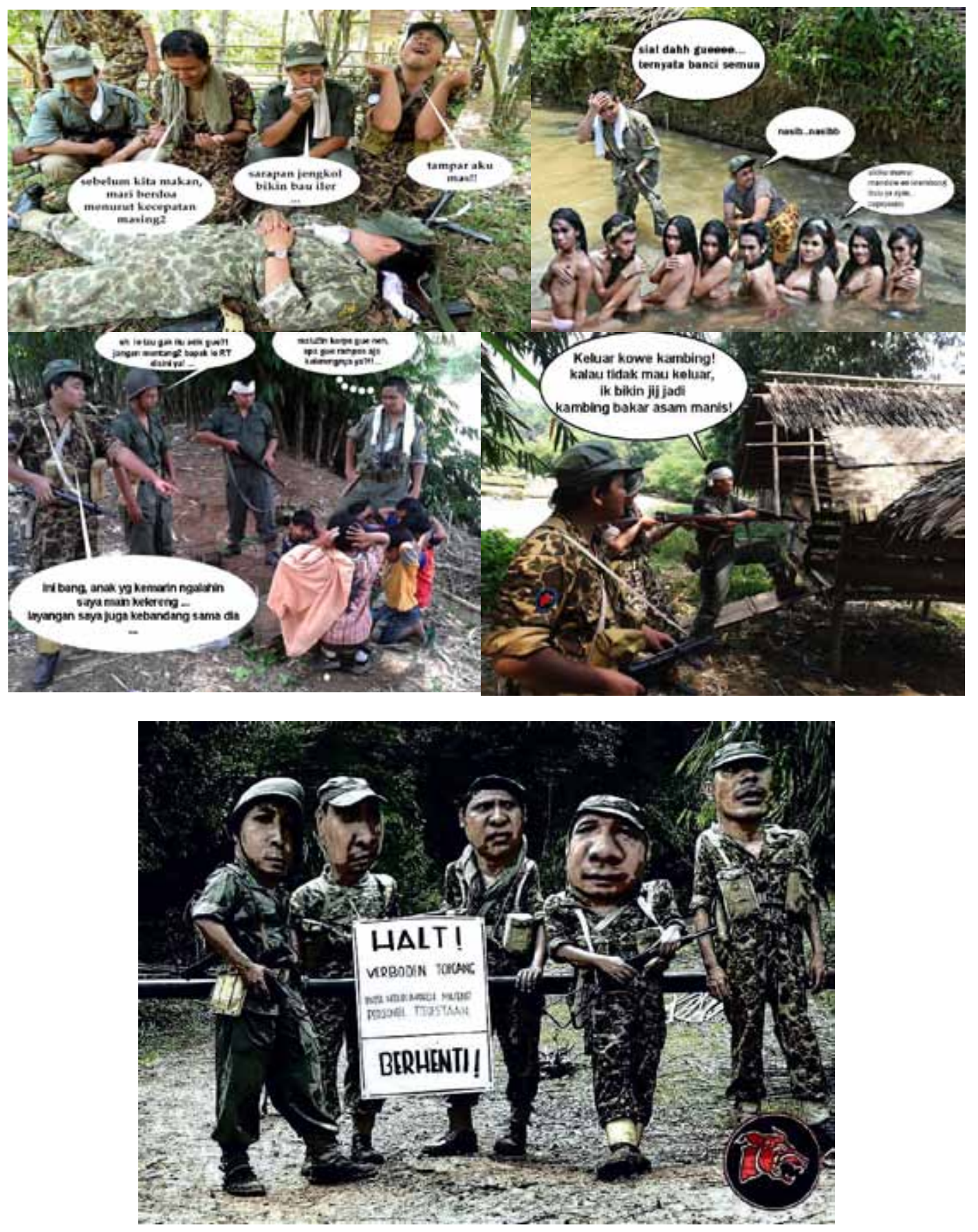

Figure 10. Mockery mimicryexpression over the visual characters of KNIL Andjing NICA's soldiers bya group of Historical van Bandoeng ina shooting session of the film Lasjkar Syetan, 2013. (Collection: HvB, 2014).

The mimicry is carried out by creating a hybrid construct of figures oriented to making fun. KNIL soldiersare now joking and ridiculous, no longer serious and scary. Reenactors, costume producersand the society reproduce new meanings adapted to the interest of self-actualization, military fashion, and spectacle in line with a contemporary point of view. On this site hegemonic power is produced since the reenactors, society, and producers' interest is controlled by capitalistic economic values. Reenactors become a part of the production process and at the same time a package of contemporary spectacle ending in one outlet, that is fashion industry. 


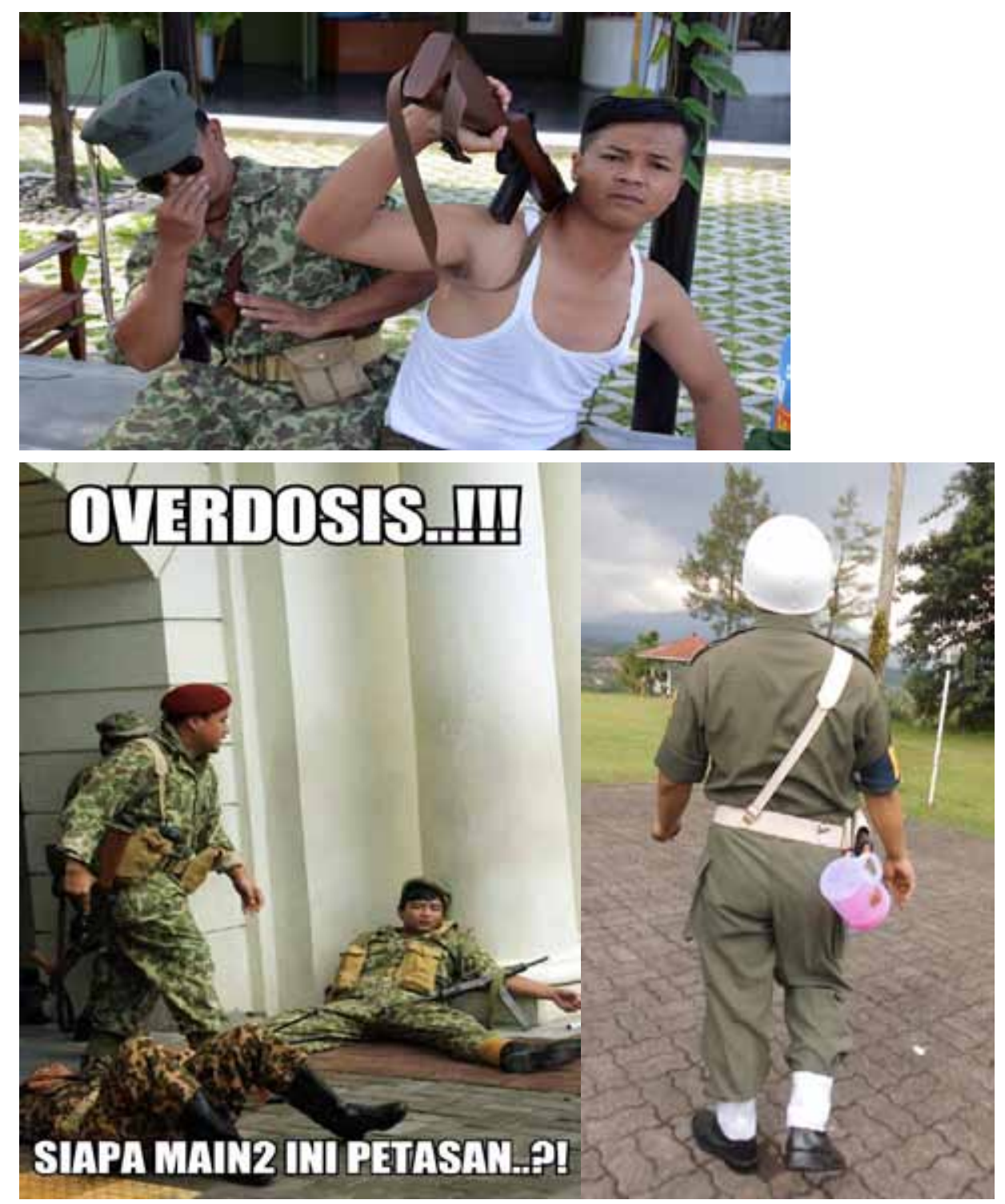

Figure 11. The reenactors' expression of the characters of KNIL Andjing NICA's soldiersinan event celebrating Serangan Oemoem 1 Maret 2015, and Magelang Kembali, 2014. (Collection: Imanez White and Febri, 2015).

Funny elements are used as a communication model among the reenactor groups that are as outstanding as the theatrical activities themselves. As if funny behavior became a 'second stage' that was more interesting, entertaining, and acceptable to the society. While the main stage was a celebration of war event or education about the military history refering to a reality, the second stage operated on a social media Facebook, being digitally edited using technology, and hyperrealitic in nature. Reenactors celebrated costumes and gears that did not produce traumatic expression, in which the war was over and a game of war just began. The story of cruelty was only memorized orally or with verbal data commonly coming from the independence supporters. The reenactorsmade more impressions of valor, pride, and allegorical nuances of historical data from the enemy of independence fighters. 


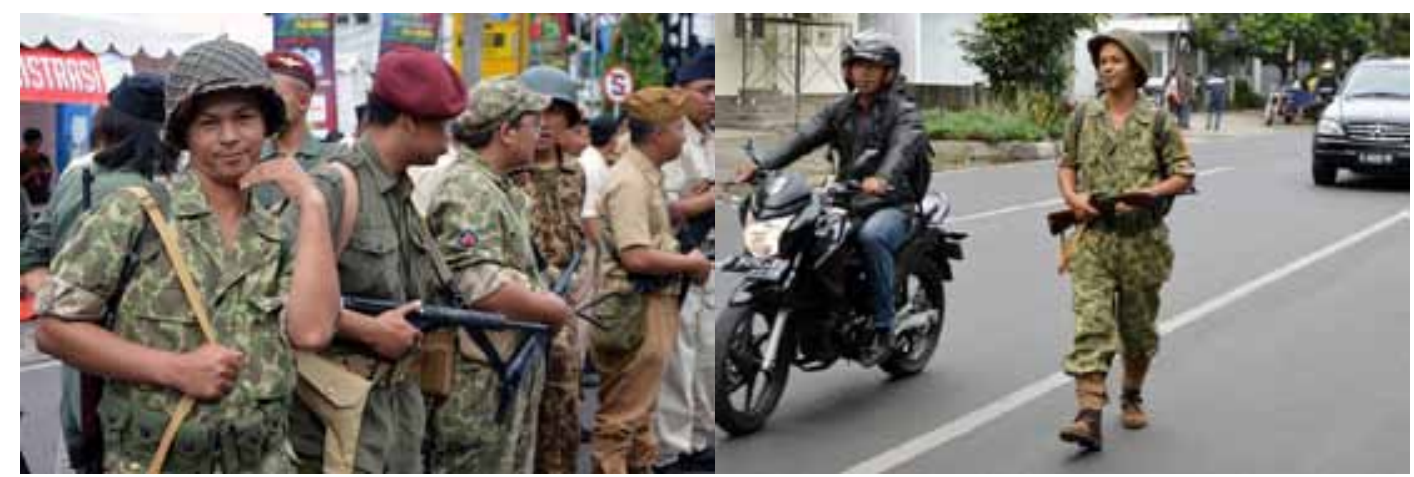

Figure 12. A KNIL reenactor with 'transgender' impression (left). The second picture is entitled 'STREES' on the Facebook wall of Agus KNIL, 28 April 2015 (right). (Collection: Agus KNIL, 2015).

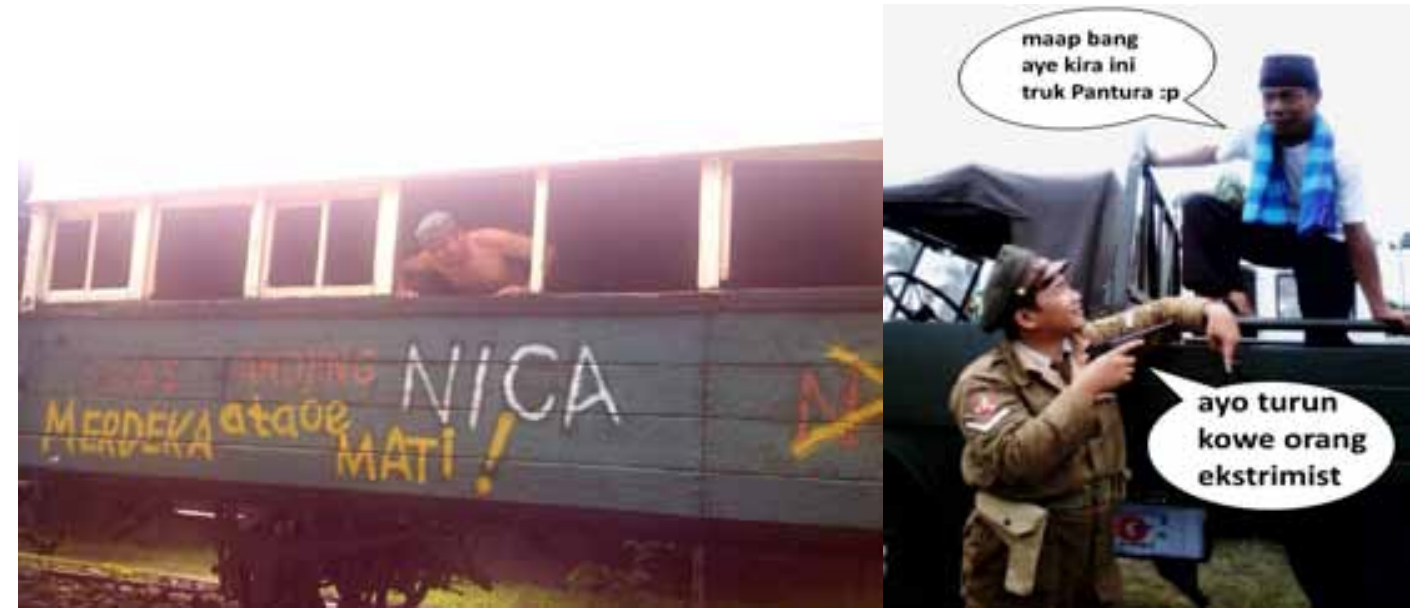

Figure 13. The picture of KNIL bare-chestreenactor on a railway coach of Ambarawa Museum (left). The picture of HvB reenactor 2013 (right). (Collection: Errol and HvB's, 2015).

c. The Space of Parody Representation

Reenactorsdo not have a complete historical view on psychological or emotional expression describing the expression forms that can be interpreted negatively about KNIL soldiers in the revolutionary era as a reference for their visual imitation.

Therefore, reenactorsmake use of their subjective imagination that tends to be pleasant and funny as a replacement for their lack of impression. The funny nuance becomes an important factor to create an appeal and brings out the audience's appreciative attitude to produce memorable situation.

Formal mimicryimpression is used as a situasional mimicryfor serious theatrical stage act, highly respecting historical authenticity. However, there will be a contrast if an reenactor loses a reference for the next mimicry. The contrast is in the form of authenticity instability, scenario instability, stage instability, impression instability, but still in situasional demand to 'stand out'. Theatrical actbased on the scenario is over, but visual character figures of KNIL Andjing NICA's soldiersremain; they still make impression and do their activities in KNIL uniforms. Thus, hybrididentityis developed when the soldiers still make impression while the scenario is over, and the appearing hybrididentity tends to be funny. 
This is used as a 'middle way' to avoid scenario lack and to maintain the existence of its mimicry. Parallel stage brings about ambivalenceas an effect of improvisation and mimicry strategythat goes out of control and lets loose each individual's subjective improvisation. Situasional ambivalencecauses humor-ambivalence and also complements humor-mimicry on the parallel stage and makes it funny.

It is assumed that there are two types of genre that operate inthe structure of visual characters of KNIL soldiersintwo stages. The first genre is oriented to historical mimicryby adopting authentic visual elements being kept and remembered from generation to the next as a form of historical heritage. The second genre is an expression of mimicry-ambivalence-mockery. Both genres occur in the third space that becomes like a 'middle way' in the dialogical relation between Western and Eastern (local) points of view because both cultural elements are needed.

This is a dialectical process that in Bhabha's concept is called the third space;Henri Lefebvre (1991) calls it a representational space; Soja (1996) uses thirdspace/trialectic spacein which the historical and social aspects among the 'parties' meet; and Foucault (1997) calls it heterotopia space (Hidayat,2013), while interms of play and theater performance this third space has the potential to produce satire and parody (Gilbert and Tomkins,1996).

Homi Bhabha's concept of third spaceappears becauseof globalisationbackground inpostcolonial situation; therefore, culture as a survival strategy goes across nations and appreciation since intensity and frequency of foreign cultural interventioninlocal spaces of each person increase. Basically, the third space is a hybridity to create a new expression, new style, and other things as a collaborative working of its constitutive elements.

War has long been over, but 'war theater' still goes on and is maintained in imaginary space. Colonialwar has been left behind and many Dutch people now feel 'guilty' or sorry for what their ancestors had done to Indonesia in the revolutionary era. However, for the reenactorsthe opposite is true. The military activity involving the character figures of KNIL Andjing NICA's soldiers will alwayshappen again and again because it becomes a fashion expression and a part of visual culture. KNIL war costume accesories have long been buried or kept in the Dutch museums with their bitter memory, but in Indonesia they are even reenacted and celebrated again through contemporary creation of stages to accomodate the post-theatrical, post-history learning, post-film watching and discussion on war films, and many others. This square mimicryis celebrated in the form of ambivalence.

\section{RESULTS}

This mimicry is celebrated by the appearance of social groups and individual organizations coming from similarity and closeness due to certain factors as a form of culture club. Reenactorculture club of KNIL Andjing NICA's soldiersappears as a fetishover the visual character of the Dutch soldiers celebrated at present. This culture club is not the next generation of KNIL, but it is understood as an artificial euphoria 
to be different, to be a hybridmimicry thatonly celebrates its visual form, as one contemporary trend to celebrate its surfacial elements.

Western culture for some Indonesians is considered as a construct related to idealization. Ducth culture as one of the representations of western culture that has a close historical bond and is taken as 'a part of Indonesian past life' turns reenactors' activityof being KNIL Andjing NICA's soldiersinto one alternative means to celebrate western idealization.Learning from historical fact that this nation won the war becauseof negotiation pressure and not because of victory in battle, the reenactorsmake use of the historical realityas something that gives a significant influence in their impression. Being visually attractive Dutch soldiers seems to be more interesting to do. Reenactors' mimicryof Dutch soldier figuresseems to be used as a psychological fulfilment for the wishes of having the Dutch virility. Showing immitation of visual character and optimal achievement quality interms of visual contestation, costumes, and accesories of impressionis considered to be a challenge to prove the reenactors' imaginary ideal of virility.

Being reenactors with visual impression of KNIL Andjing NICA's soldiersis an attempt to make a visual reconstruction. This becomes what Strinati $(2007,263)$ called 'retro-nostalgia',namely an attempt to recycle the past in a different way since the excavation of historical values is covered in artificial elements. This recycle is an effort to grow retrospective attitude in the antagonist groups and also to deconstruct negative stigma published in conventional media. Reenactors create a parallel stage as a new construct for antagonist figure who is no longer scary but is now a pleasant, iconic, and populist figureand yet having opposite point of view from the old one. Reenactors of KNIL Andjing NICA's soldiers are a representation of the effort to make a social regroupping. This means that the making of social group that is based on demographic and geographic aspects is considered to be obsolete. The newly created groups are based on the similarity of hobby and mindset or point of view (based on psychographic aspects). This is at the same time a new way or bonding element in the making of social group.

The factors of newness like similarity in impression of KNIL soldiers, fetish sublime dependence on the soldier's costume (authentic, relic, battle-proven) and having affiliation with the allied groups are used to preserve the need for mimicry. This need continuously grows in line with fashion fulfilment other than costumes and accesories, namely contemporary lifestyle and mindset to satisfy the desire for products controlled by production machines. The desire to have is a foundation for contemporary life that seems to be controlled by global capitalism. The desire operates through a worshipping mechanism on goods that are not substantiallyneeded. The desire through global capitalism changes want into need. Need is created; it produces not only goods but also need; the desire lies behind the need to preserve the production.

Being reenactorsof KNIL Andjing NICA's soldiers seems to be an alternative to enjoy an old lifestyle as has been done previously at the nostalgia celebration of past lifestyle, 
for instancelove for old furnitures, local heritage of culinary recipe, old transportation, colonial house model, and many others (see Lim \& Hidayati, 2010). Inthe celebration of enjoying the past lifestyle, the reenactorscombine and mix up the related elements disregarding time, disregarding function of goods elements (for example an army cup hung on the trooper's knapsack), mixing reality with imagination, reality with hyperreality, and others as a celebration of mimicry.

Mockery mimicry then becomes an expression of hybrid ambivalence when the newly created figure is even in constrast with the constituting elements. For example, the replica of 1945-1950 KNIL Andjing NICA's soldiers at present carrying android smart phones, or doing an activity and interacting with the people in the theatrical event, becoming extras at war film, going on a tour to Yogja palace, taking pictures with royal servants. However, they are still responsible citizens and play their role as good ones by joining the presidential general election or helping police officers manage the traffic. A group of individuals like this views colonial military uniforms as fashion, old-fashioned clothes being liked and appreciated or chosen as an alternative to attend a wedding party or prewedding event, to be wedding guest receptionists, and many others.

I understand this as a phenomenon of postcolonial cultural expression construct, a cultural 'attempt' appearing incontemporary social life becauseof postcolonial influence. In other words, it is an appreciative attitude over interconnected points of view that people have on colonial artifacts influencing the identity of the people at present, as an expression, formative discourseor iconic sign of contemporary life (see Setiawan, 2014:438). The formative discourse becomes a kind of culture, a word that has three orientations in Williams' terms (1983).

First, it is a term referring to a general process of intellectual, spiritual, and aesthetic development. Second, it refers to a certain worldview of the people, period, or group. Third, it relates to the intellectual works and practices, especially artistic activities. Substantially, the activities have the main function to show, signify, produce, or sometimes to be events that build certain meanings. Culture in the third sense is synonimous with what the structuralists and poststructuralists call 'signifying practices' (Williams, 1983: 90). Applied on the material objects of this research, the phenomena of visual character of KNIL soldiers embodied in all activities and operations/consequences of the signifying strategy are a kind of social practices and discoursecarried out in the contemporary life. This is the reenactors' attemptto produce certain signs and also meanings to be conveyed through their artistic activities.

Reenactors reproduce the visual characteristics of KNIL Andjing NICA's soldiers through chains of mimic-hybridmozaic, but their production seems to be an effort to deconstruct their historical stigma. Reenactors deconstruct and reconstruct the negative view and hatred passed on from one generation to the nextby applying various new expressions as a result of mimicry, hybridity, ambivalence, mockery, visualization desires, fetish, and media technology. This is a form of cultural postcoloniality, in which understanding of meaning and visual operation of 
postcoloniality has been constructed 'beyond' the limitations of binary oppositions like traditional-modern-postmodern, real-imaginary, past-contemporary, serious-funny, and other blurred meanings. This is one of the phenomena of cultural postcoloniality. The third space as a stage of cultural postcoloniality inthis researchcan be visualized with the following chart:

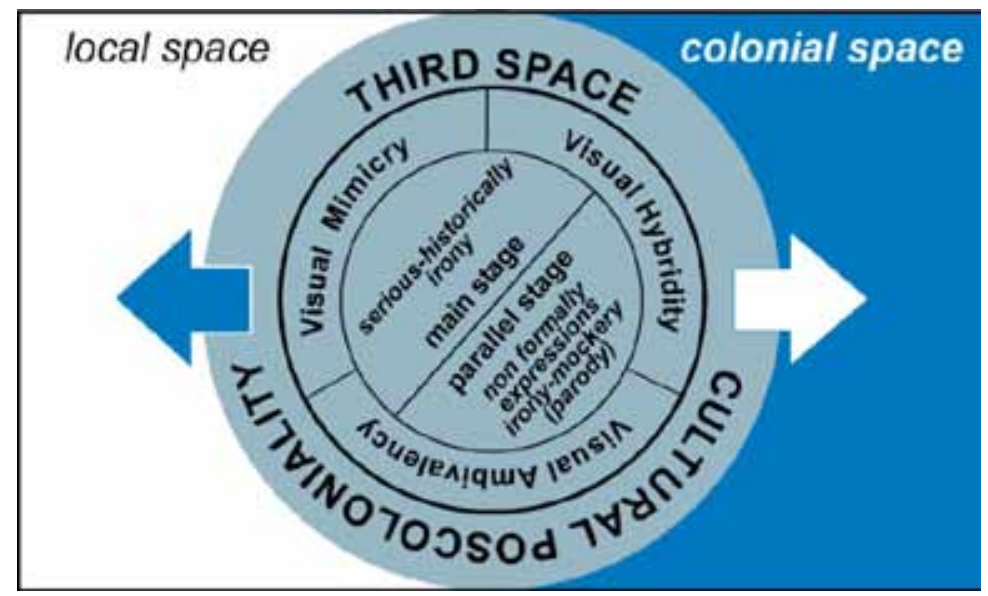

Figure 14. Third space chart (cultural postcoloniality) as a kind of tug-of-warbetween modern, civilized, and superior colonial space, and traditional, uncivilized, and inferior local space. (Collection: Dektisa, 2015).

\section{CONCLUSION}

Imitation of the characteristicsof KNIL NICA's soldierswhen related to postcolonial theory is understood as an attempt of visual mimicry. However, mimicrydoes not work perfectly when the impression display cannot be fully visualized. There is a lack of historical visual patterns that are added from the reenactors' imaginary space. The effort to fill the lack can also be interpreted as a part of subjective psychological expression and at the same time an attempt to reach catharsis and seflactualizationthrough the impression they carry out. The filling expression of absent patterns and the effort of self-actualization become the 'third space' or 'dialogical space' that is 'affirmation space' betweenthe individual subject who still has a traditional point of view on the second space consisting of modern procedures and structure inthe context of colonialorientation. Inthis very third space, reenactorsexpress their social activities and construct meanings and signs categorized as formal discourse and become a part of cultural postcoloniality. This culture becomes an alternative procedure that helps reshape contemporary social life.

The third space also becomes a channel/medium for euphoria of subjectivity and a space for optimalizing character visualization of KNIL Andjing NICA's soldiers. However, the third space cannot accomodate the power of imaginative mimicry impression that is ambivalent in nature. Since, besides displaying postcolonial expression deriving from traditional and colonial faces, the third stage accomodates various needs of impression and replica activities. Inthis research, the third space is 
parallel stages, namely when visual mimicryproduced develops into hybridityand gets ambivalentinaccomodating various needs of reenactors' activitiesin their contemporary social life.

\section{REFERENCES}

Ashcroft B, Gareth G and Hellen T. (2001). The Empire Writes Back, Theory and Practice in Post-colonial Literatures. Routledge Publisher, London. . (2003). Menelanjangi Kuasa Bahasa: Teori dan Praktik Sastra Poskolonial. Qalam, Yogyakarta. . (1995). The Post-colonial Studies Reader. Routledge Publisher, London.

Bhabha, H.K. (1994). The Location of Culture. London \& New York: RoutledgeTaylor \& Francis e-Library.

Barnard, Malcom. (2005). Fashion Sebagai Komunikasi, Cara Mengkomunikasikan Identitas Sosial, Seksual, Kelas dan Gender. (Terj. Idi Subandy Ibrahim). Penerbit Jalasutra, Yogyakarta.

Barthes.R. (1997). The fashion system (trans. by Matthew W. and Richard H.). University of California Press, London.

Murwani, Christina Dewi Tri. (2007). "Max Havelaar dan Citra Antikolonial: Sebuah Tinjauan Poskolonial." Tesis Program Studi Ilmu Sastra Sekolah Pascasarjana Universitas Gadjah Mada, Yogyakarta.

Strinati. D. (2003). Popular Culture, an Introduction to Theories of Popular Culture, Terj.: Abdul Mukhid, Popular culture, pengantar menuju teori budaya populer. Penerbit Jejak, Yogyakarta.

Sturken\&Cartwright. (2004). Practices of Looking: an Introduction to Visual Culture, Oxford University Press, London.

Williams. R. (1983). Keywords: a Vocabulary of Culture and Society. Oxford University Press, New York.

\section{CONFERENCE PAPER}

Setiawan, Ikhwan. (2013). Jelajah Pemikiran Budaya. Makalah di diskusi Pusat Studi Kebudayaan UGM, Yogyakarta. 